\title{
2007 ve 2018 Deprem Yönetmeliklerinin Yapısal Analizler Ișı̆̆ında Karşılaştırılması
}

\author{
Kübra Adar ${ }^{1}$, Aydın Büyüksaraç ${ }^{2}$, Ercan Işık ${ }^{3}$, Ali Emre Ulu ${ }^{4 *}$ \\ ${ }^{1}$ Dicle Üniversitesi, Fen Bilimleri Enstitüsü, İnşaat Müh. Bölümü, Diyarbakır, Türkiye, (ORCID: 0000-0001-6595-2879), kubra_adar05@hotmail.com \\ ${ }^{2}$ Çanakkale Onsekiz Mart Üniversitesi, Çan Meslek Yüksek Okulu, Çan Çanakkale, Türkiye (ORCID: 0000-0002-4279-4158), absarac@comu.edu.tr \\ ${ }^{3}$ Bitlis Eren Üniversitesi, Mühendislik Mimarlık Fakültesi, İnşaat Müh. Bölümü, Bitlis, Türkiye (ORCID: 0000-0001-8057-065X), ercanbitliseren@gmail.com \\ 4* Bitlis Eren Üniversitesi, Mühendislik Mimarlık Fakültesi, İnşaat Müh. Bölümü, Bitlis, Türkiye (ORCID: 0000-0001-7499-3891), aliemreulu@gmail.com
}

(İlk Geliş Tarihi 30 Mart 2021 ve Kabul Tarihi 27 Haziran 2021)

(DOI: $10.31590 /$ ejosat.906347)

ATIF/REFERENCE: Adar, K., Büyüksaraç, A., Işık, E., \& Ulu, A.E. (2021). 2007 ve 2018 Deprem Yönetmeliklerinin Yapısal Analizler Işı̆̆ında Karşılaştırılması. Avrupa Bilim ve Teknoloji Dergisi, (25), 306-317.

$\ddot{O} \mathbf{z}$

Depremlerden dolayı meydana gelen yapısal hasarları ve bu hasarlar sonucu oluşan can kayıplarını en aza indirmek amacıyla depreme dayanıklı yapı tasarım kuralları hazırlanmaktadır. Bilimsel gelişmeler, yapım teknolojileri ve yapı malzemelerindeki yenilikler ile depremde oluşan hasarların birlikte dikkate alınması sonucu, yenilenme ve değişim ihtiyacı kaçınılmazdır. Bu çalışma kapsamında 2007 ve 2018 deprem yönetmelikleri arasında karşılaştırmalar yapılmıştır. Kullanılan yazılımın uygun sürümleri kullanılarak, örnek olarak seçilen on beş katlı betonarme bir yapı her iki yönetmelik için analiz edilerek sonuçlar karşılaştırılmıştır. Analizler sonucu örnek olarak incelenen bina için değişimler belirtilerek, yorumlar yapılmıştır.

Anahtar Kelimeler: Deprem, Yönetmelik, Yapısal Analiz, Betonarme, Zemin

\section{Comparison of 2007 and 2018 Seismic Codes in the Scope of Structural Analysis}

\begin{abstract}
In order to minimize the structural damages caused by earthquakes and the loss of life resulting from these damages, earthquake resistant building design rules are prepared. The need for renewal and change is inevitable as a result of scientific developments, innovations in construction technologies and building materials and taking into account the damage caused by the earthquake. Within the scope of this study, comparisons were made between 2007 and 2018 seismic design codes. As an example, a fifteen-storey reinforced concrete structure selected was analyzed for both regulations and the results were compared by using the appropriate versions of the software that used in this study. Changes were indicated for the sample RC building as a result of structural analyses and comments were made.
\end{abstract}

Keywords: Earthquake, Regulation, Structural Analysis, Reinforced Concrete, Soil

*Sorumlu Yazar: aliemreulu@gmail.com 


\section{Giriş}

Depremler sonucu oluşan yapısal hasarlar ile zaman içerisinde gelişen yapım teknolojileri ve yapı malzemelerinin de etkisi ile depreme dayanıklı yapı tasarım ilkelerinde değişikliklere gidilmesi kaçınılmazdır. Elde edilen deprem hasar verileri, yap1 ile ilgili yönetmeliklerin gelişmesine önemli katkılar sunmaktadır. Türkiye, yaşadığı acı deprem olayları sonucu bu kurallarda önemli değişikliklere gitmiştir. Farklı tarihlerde kuralların bir kısmı güncellenerek ya da tamamen değiştirilerek, 1 Ocak 2019 yürürlüğe girerek en son şeklini almıştır.
Afetler hakkında ilk düzenleme 14.09.1509 tarihinde İstanbul'da meydana gelen yaklaşık 13.000 kişinin ölümüne neden olan deprem sonrası II. Bayezid'in çıkardığı fermana dayanmaktadır (Kemaloğlu, 2015). 26 Aralık 1939'da Erzincan da gerçekleşen ve çok büyük yıkıma sebebiyet veren bu deprem sonrası ilk yönetmelik hazırlanmıştır (Öztürk, 2018). İlk olarak 1940 "Zelzele Mıntıkalarında Yapılacak İnşaata Ait İtalyan Yapı Talimatnamesi" yayınlanmış ve günümüze kadar değişimlere uğrayarak farklı şekillerde ilan edilmiştir (Tablo 1) (Alyamaç ve Erdoğan, 2005).

Tablo 1. Yönetmeliklerin tarihsel değişimi

\begin{tabular}{c|l}
\hline \multirow{2}{*}{ Yönetmelik Tarihi } & \multicolumn{1}{c}{ Yönetmeliğin Adı } \\
\hline 1940 & Zelzele Mıntıkalarında Yapılacak Inş̧aata Ait İtalyan Yapı Talimatnamesi \\
\hline 1944 & Zelzele Mıntıkaları Muvakkat Yapı Talimatnamesi \\
\hline 1949 & Türkiye Yer Sarsıntısı Bölgeleri Yapı Yönetmeliği \\
\hline 1953 & Yersarsintısı Bölgelerinde Yapılacak Yapılar Hakkında Yönetmelik \\
\hline 1962 & Afet Bölgelerinde Yapılacak Yapılar Hakkında Yönetmelik \\
\hline 1968 & Afet Bölgelerinde Yapılacak Yapılar Hakkında Yönetmelik (ABYYHY-1968) \\
\hline 1975 & Afet Bölgelerinde Yapılacak Yapılar Hakkında Yönetmelik (ABYYHY-1975) \\
\hline 1998 & Afet Bölgelerinde Yapılacak Yapılar Hakkında Yönetmelik (ABYYHY-1998) \\
\hline 2007 & Deprem Bölgelerinde Yapılacak Binalar Hakkında Yönetmelik (DBYBHY-2007) \\
\hline 2018 & Türkiye Bina Deprem Yönetmeliği (TBDY-2018) \\
\hline
\end{tabular}

1940 Zelzele Mıntıkalarında Yapılacak İnşaata Ait İtalyan Yap1 Talimatnamesi'nde, henüz betonarme yapıların yaygınlaşmadığı bu dönemde mimari özelliklere yer verilmiş, duvar kalınlığı, kat yüksekliği gibi konular üzerinde durulmuştur. 1944 Zelzele Mıntıkaları Muvakkat Yapı Talimatnamesi’nde başlangıç olarak resmi işlere, ruhsat ve cezai hükümlere yer verilmiştir. Betonarme yapılara değinilmiş ancak ayrıntılara yer verilmemiștir.1940 talimatnamesinden farklı olarak temel zemininden söz edilmiş ve bina uzunlukları hakkında sınırlar belirtilmiştir. Bir bina inşası için en uygun olan malzeme ve itinalı işçilik kavramı anlatılmıştır (Parlar, 2019). 1949 Türkiye Yersarsıntısı Bölgeleri Yapı Yönetmeliği'nde, detaylı olmamakla birlikte 1. ve 2. derece deprem bölgeleri hakkında hükümler getirilmiştir. Temel kazık ya da radyejeneral temel kullanma zorunluluğu başlatılmıştır. Deprem etkisine düşey etkinin yanında, yatay etkinin de ele alınması gerektiği vurgulanmıştır. Yatay deprem etkisinin kesiştiği iki dik eksen üzerinde etki ettiğini ancak iki doğrultu üzerinde de eşit derecede etki göstermediği ifade edilmiştir (Alyamaç ve Erdoğan, 2005; Emlakansiklopedisi, 2018). 1968 yılındaki yönetmelik genel olarak farklı türdeki doğal afetler için korunma yolları ile tasarım kuralları içermektedir. Betonarme terimi ilk defa bu yönetmelikte kendine yer bulmuştur. Yapıların mümkün olduğu kadar basit olarak inşa edilmesi önerilmektedir ABYYHY, 1968). ABYYHY1968 'in güncel hali 1975 yönetmeliğinde kendine yer bulmuştur. $\mathrm{Bu}$ yönetmelik, su, yangın ve deprem afetinden korunmak başlıkları altında yayınlanmıştır (ABYYHY, 1975). Yapı önem derecesi, hareketli yük azaltma katsayıları ilk kez bu yönetmelik ile ifade edilmiştir.

1999 y1lında oluşan İzmit (Gölcük) Mw=7.6 ve Düzce $\mathrm{Mw}=7.2$ büyüklüğünde depremlerde oluşan büyük çaplı can ve mal kayıpları 1998 yönetmeliğinin güncellenmesi gerekliliği sonucu 2007 yılında oluşturulmuştur. 2007 Deprem Bölgelerinde Yapılacak Binalar Hakkında Yönetmelik (DBYYHY, 2007) Marmara Depremi sonrası oluşan ciddi kayıplar nedeniyle 1998 Afet Bölgelerinde Yapılacak Yapılar Hakkındaki Yönetmelik'in belirli kısımları değiştirilip düzenlenerek ilan edilmiştir (ABYYHY, 1998). Bu düzenlemeler içerisinde en önemli değişim, performans analizinin zorunlu kılınması olmuştur (DBYYHY, 2007). Bu yönetmelikte köklü değişikliklerin yapılmamış olması ve değiş̧en bilimsel ve teknik koşullardan kaynaklı tekrar değiştirme gereği duyulmuştur. İlk değişim 2016 yılında hazırlanan taslak oluşumuyla yapılıp son olarak Mart 2018'de Türkiye Bina Deprem Yönetmeliği hazırlamış ve 1 Ocak 2019 tarihinde yürürlüğe girmiştir. Bu yönetmelik hem deprem açısından hem de yapısal olarak incelenip daha geniş bir çerçevede sunulmuştur. Son iki yönetmelik arasındaki değişimleri inceleyen birçok çalışma bulunmaktadır. $\mathrm{Bu}$ çalışmalar, genel olarak spektrum eğrilerindeki değişimlerin yapı performansına etkisi, kesit hasar seviye değişimlerinin incelenmesi, tasarım spektral ivme katsayılarındaki değişim, taşıyıcı sistem performans değişimlerinin incelenmesi, il ve bölge bazında değişmlerin incelenmesi ve benzer konularda yapılmıştır (Işık vd. 2021; Sümer ve Hamsici, 2020; Işık vd., 2020; Aksoylu ve Arslan, 2021; Karaşin vd., 2020; Ulutaş, 2019; Bozer, 2020; Dalyan ve Şahin, 2019; Keskin ve Bozdoğan, 2018; Aksoylu vd., 2020; Nemrutlu vd. 2020). Ayrıca yapıların deprem etkisi altındaki davranışlarının belirlenmesi deprem mühendisliği açısından önemli bir yere sahiptir (Özyurt ve Hayvalı, 2020; Işık vd., 2020; Aktaş ve Karaşin, 2014). Bu çalışma kapsamında son iki deprem yönetmeliği arasındaki temel farklılıkların yanı sıra yapısal analizlere etkileri ortaya konmaya çalışılmıştır. 


\section{Yöntem}

Çalışmanın temel amacı, 2007 ve 2018 deprem yönetmelikleri arasındaki farkları belirlemek ve örnek bir betonarme bina için yapısal analiz sonuçlarının hangi ölçüde değiştiğinin ortaya konulmasıdır. Bu bağlamda her iki yönetmelik olabildiğince detaylı incelenmeye çalışılmıştır. 7 genel bölümden oluşan DBYYHY-2007, 31.12.2018'de yürürlükten kaldırılmıștır. TBDY-2018, 17 bölüm ve 395 sayfadan oluşturulmuş ve 01.01.2019'da yürürlüğe konulmuştur. Son deprem yönetmeliği bu bağlamda daha detaylı olarak hazırlanmıştır. DBYYHY-2007, betonarme, çelik ve yığma binalar ile ilgili tasarım kurallarını içerirken, bu yapıların yanı sıra deprem tesirindeki yerinde dökme ve ön üretimli betonarme, hafif çelik, karma ve ahşap malzemelerden yapılacak binalar için kuralları içermektedir. Yeni deprem yönetmeliğindeki en büyük değişiklik herhangi bir coğrafi konuma göre sahaya özgü deprem tehlikesinin hesaplanabilmesidir. DBYYHY-2007'de bölgesel bazda yapılan hesaplamalar artık konuma özel olarak gerçekleşmektedir. Kısaca makro boyuttan mikro boyutta deprem tehlikesi hesaplanmaya başlanılmıştır. Deprem bölgelendirme haritası yerine Türkiye Deprem Tehlike Haritası kullanılmaya başlanmıştır. DBYYHY-2007'de deprem bölgeleri beş farklı bölge ile ifade edilmiş olup ivme değerleri $0.1 \mathrm{~g}-0.4 \mathrm{~g}$ arasında değişen değerler almaktadır. TBDY-2018, noktaya özel hesaplama gerektirmekte ve bu hesaplamalar İnteraktif Deprem Web Uygulaması ile doğrudan gerçekleştirilmektedir. İki yönetmelikte dikkate alınan deprem tehlike haritaları Şekil 1'de gösterilmiştir.
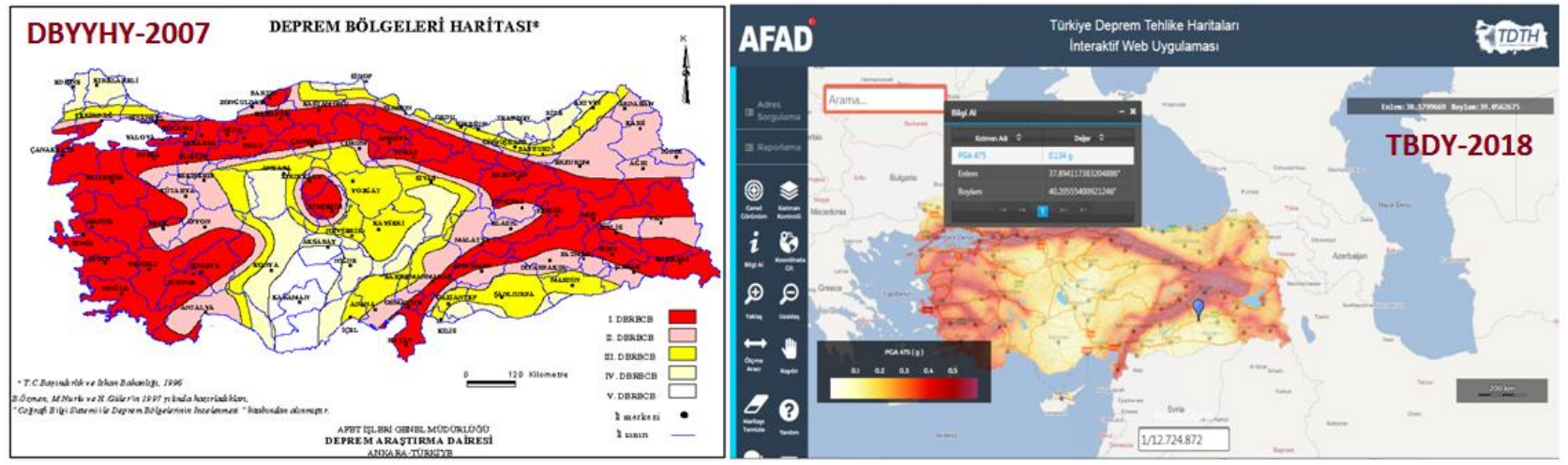

Şekil 1: Son iki deprem yönetmeliğinde deprem tehlike haritaları (AFAD, 2018)

DBYYHY-2007'de deprem düzeyi herhangi bir simge ile ifade edilmemekle birlikte tüm yapılacak yapılarda 50 yılda aşılma olasılığı \%10, tekrar oluşma periyodu 475 yıl olarak belirtilen depremler için kullanılmıştır.
TBDY-2018'de dört farkl1 deprem yer hareket düzeyi öngörülmüştür ve her bir yer hareket düzeyi DD simgesi ile belirtilmiş̧ir (TBDY, 2018). Bu deprem düzeyleri Tablo 2‘de gösterilmiştir.

Tablo 2. Deprem yer hareketi düzeyi (TBDY-2018)

\begin{tabular}{l|l|l|l}
\hline Deprem Düzeyi & Tekrarlanma Periyodu & Așılma Olasılığı (50 yılda) & \multicolumn{1}{c}{ Tanımı } \\
\hline$D D-1$ & 2475 & 0.02 & En büyük deprem yer hareketi \\
\hline$D D-2$ & 475 & 0.10 & Standart tasarım deprem yer hareketi \\
\hline$D D-3$ & 72 & 0.50 & Sik deprem yer hareketi \\
\hline$D D-4$ & 43 & 0.68 & Servis deprem hareketi \\
\hline
\end{tabular}

Yeni yönetmelik ile etkin ivme katsayısı yerine, tasarım ivme spektrumu, harita spektral ivme katsayısı ve yerel zemin etki katsayıları kullanılmaktadır. Bu parametrelerin kullanılması ile ülkemizde yer alan her bir nokta için harita spektral ivme katsayıları $\left(\mathrm{S}_{\mathrm{S}}\right.$ ve $\left.\mathrm{S}_{1}\right)$ dikkate alınarak tasarım ivme katsayıları $\left(\mathrm{S}_{\mathrm{DS}}\right.$ ve $\left.\mathrm{S}_{\mathrm{D} 1}\right)$ kullanılarak elde edilen ivme spektrumları kullanılacaktır. Böylelikle daha önce binanın bulunduğu deprem bölgesine bağlı olarak tek bir değer alan spektral ivme katsayısı, kısa ve uzun periyot bölgeleri için ayrı ayrı belirlenecektir. Her iki yönetmelikte yer alan spektrum eğrilerinin karşılaştırılması ise Şekil 2'de verilmiştir. Ayrıca DBYYHY-2007'de ifade edilmeyen düşey elastik tasarım spektrumu, TBDY-2018 ile ilk kez deprem yönetmeliklerinde kendine yer bulmuştur. Yerel zemin özellikleri yapıların deprem davranışını doğrudan etkilemektedir (Borcherd, 2004; Över, vd. 2011; Büyüksaraç, vd. 2013; Karaşin ve Iş1k, 2017; Işık, vd. 2016; Işık ve Kutanis, 2015; Yakut vd., 2014). Bu bağlamda TBDY-2018'de iki farklı yerel zemin katsayısı ile ifade edilmiştir $\left(F_{S}\right.$ ve $\left.F_{1}\right)$. $F_{S}$, kısa periyot bölgesi için yerel zemin etki katsayısını ifade ederken $F_{1}, 1.0$ saniye periyot için yerel zemin etki katsayısını belirtmektedir. DBYYHY-2007'de Bina Önem Katsayısı (I), 1.0, 1.2, 1.4 ve 1.5 olmak üzere dört farklı değer almaktadır. Bina Önem Katsayısı (I), TBDY-2018'de de kullanılmaya devam edilmesine rağmen $1.0,1.2$ ve 1.5 olmak üzere üç farklı değer almaktadır. İnsanların uzun süreli ve yoğun olarak bulunduğu ve değerli eşyanın saklandığı binalar için DBYBHY-2007'de 1.4 değeri kullanırken, bu değer yeni deprem yönetmeliğinde daha önceki 1.5 değerinin olduğu yapı grubu ile birleştirilerek 1.5 olarak dikkate alınmaya başlanmıştır. TBDY2018'de bu katsayı hesaplanırken, DBYYHY-2007'de belirtilmeyen Bina Kullanım Sınıfı (BKS) da yeni yönetmelikte kendine yer bulmuştur. 


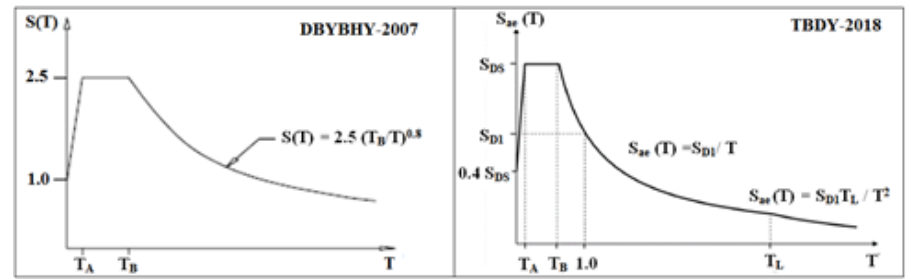

Şekil 2: Spektrum ĕgrilerinin karşılaştırılması

DBYYHY-2007'de zemin grupları A, B, C ve D olarak 4 gruba ayrılmış ve hangi zemin türü olduğu yapılacak zemin etütleri sonucunda belirlenmekteydi. A'dan D'ye doğru gidildikçe zeminin taşıma gücü düşmekteydi (Tablo 3). Ayrıca bu yönetmelikte zemin gruplarının yanı sıra zemin sınıfları dört farklı şekilde sınıflandırılmakta idi (Z1, Z2, Z3 ve Z4) (Tablo 4). Yeni yönetmelik ile zemin grup ve sınıfları birleştirilerek Yerel Zemin Sınıfı olarak adlandırılmaya başlanmıştır (Tablo 5).

TBDY-2018'de ilk kez deprem tasarım sınıfları yer almıştır. Bina kullanım sınıflarına ve DD-2 deprem yer hareketi düzeyi için Kısa Periyot Tasarım Spektral İvme Katsayısına bağlı olarak deprem tasarım sınıfları tanımlanmıştır. Deprem tasarım sınıfları Tablo 6'de belirtilmiştir. Deprem yönetmeliklerimize giren yeni bir ifadede, Bina Yükseklik Sınıfı (BYS)'dir. TBDY-2018'de deprem etkisi altında bina yükseklik sınıfları sekiz farklı gurupta sunulmuştur (Tablo 7).

Tablo 3: DBYBHY-2007 yönetmeliğine göre zemin gruplaması

\begin{tabular}{|c|c|c|c|c|c|}
\hline $\begin{array}{l}\text { Zemin } \\
\text { Grubu }\end{array}$ & Zemin Grubu Tanımı & $\begin{array}{l}\text { Stand. } \\
\text { Penetr. } \\
(\mathrm{N} / 30)\end{array}$ & $\begin{array}{l}\text { Rölatif } \\
\text { Sıklık } \\
(\%)\end{array}$ & $\begin{array}{l}\text { Serbest } \\
\text { Basınç } \\
\text { Direnci } \\
(\mathrm{kPa})\end{array}$ & $\begin{array}{l}\text { Kayma } \\
\text { Dalgası } \\
\text { Hizı } \\
(\mathrm{m} / \mathrm{s})\end{array}$ \\
\hline (A) & $\begin{array}{l}\text { 1. Masif volkanik kayaçlar ve } \\
\text { ayrışmamış sağlam metamorfik } \\
\text { kayaçlar, sert çimentolu tortul } \\
\text { kayaçlar... } \\
\text { 2. Çok sıkı kum, çakıl... } \\
\text { 3. Sert kil ve siltli kil... }\end{array}$ & $\begin{array}{l}- \\
>50 \\
>32\end{array}$ & $\begin{array}{l}- \\
85-100 \\
-\end{array}$ & $\begin{array}{l}>1000 \\
- \\
>400\end{array}$ & $\begin{array}{l}>1000 \\
>700 \\
>700\end{array}$ \\
\hline (B) & $\begin{array}{l}\text { 1. Tüf ve aglomera gibi gevşek } \\
\text { volkanik } \quad \text { kayaçlar, } \\
\text { düreksizlik } \\
\text { çimenteri bulunan } \\
\text { ayrışmış } \\
\text { 2. Sıkı kum, çakıl... } \\
\text { 3. Çok katı kil ve siltli kil... }\end{array}$ & $\begin{array}{l}- \\
30-50 \\
16-32\end{array}$ & $\begin{array}{l}- \\
65-85 \\
-\end{array}$ & $\begin{array}{l}500-1000 \\
- \\
200-400\end{array}$ & $\begin{array}{l}700-1000 \\
400-700 \\
300-700\end{array}$ \\
\hline (C) & $\begin{array}{l}\text { 1.Yumuşak süreksizlik düzlemleri } \\
\text { bulunan çok ayrışmıs metamorfik } \\
\text { kayaçlar ve çimentolu tortul } \\
\text { kayaçlar... } \\
\text { 2. Orta sıkı kum, çakıl... } \\
\text { 3. katı kil ve siltli kil... }\end{array}$ & $\begin{array}{l}- \\
10-30 \\
8-16\end{array}$ & $\begin{array}{l}- \\
35-65 \\
-\end{array}$ & $\begin{array}{l}<500 \\
- \\
100-200\end{array}$ & $\begin{array}{l}400-700 \\
200-400 \\
200-300\end{array}$ \\
\hline (D) & $\begin{array}{l}\text { 1. Yeraltı su seviyesinin yüksek olduğu } \\
\text { yumuşak, kalın alüvyon tabakaları... } \\
\text { 2. Gevşek kum... } \\
\text { 3. Yumuşak kil, siltli kil... }\end{array}$ & $\begin{array}{l}- \\
<10 \\
<8\end{array}$ & $\begin{array}{l}- \\
<35\end{array}$ & $\begin{array}{l}- \\
- \\
<100\end{array}$ & $\begin{array}{l}<200 \\
<200 \\
<200\end{array}$ \\
\hline
\end{tabular}


Tablo 4: DBYBHY-2007 yönetmeliğine göre zemin sinıflamasl

\begin{tabular}{c|c}
\hline $\begin{array}{c}\text { Yerel Zemin } \\
\text { Sınıfı }\end{array}$ & Zemin Grubu ve \\
& En Üst Zemin Tabakası Kalınlığı (h1) \\
\hline \multirow{2}{*}{$Z 1$} & $h 1 \leq 15$ m olan $(B)$ grubu zeminler \\
\hline \multirow{2}{*}{$Z 2$} & $h 1>15$ m olan $(B)$ grubu zeminler \\
& $h 1 \leq 15$ m olan $(C)$ grubu zeminler \\
\hline \multirow{2}{*}{$Z 3$} & $15 m<h 1 \leq 50$ m olan $(C)$ grubu zem. \\
& $h 1 \leq 10$ m olan $(D)$ grubu zeminler \\
\hline \multirow{2}{*}{$Z 4$} & $h 1>50$ m olan $(C)$ grubu zeminler \\
& $h 1>10$ m olan $(D)$ grubu zeminler \\
\hline
\end{tabular}

Tablo 5: TDBY-2018 yönetmeliğine göre zemin sinuflamasl

\begin{tabular}{|c|c|c|c|c|}
\hline \multirow[b]{2}{*}{$\begin{array}{c}\text { Yerel } \\
\text { Zemin } \\
\text { Sinıfi }\end{array}$} & \multirow[b]{2}{*}{ Zemin Cinsi } & \multicolumn{3}{|c|}{ Üst 30 metrede ortalama } \\
\hline & & $\begin{array}{l}(V s) 30 \\
{[\mathrm{~m} / \mathrm{s}]}\end{array}$ & $\begin{array}{c}(\mathrm{N} 60) 30 \\
{[\text { darbe/ }} \\
30 \mathrm{~cm}]\end{array}$ & $\begin{array}{l}(\mathrm{cu}) 30 \\
{[\mathrm{kPa}]}\end{array}$ \\
\hline$Z A$ & Sağlam, sert kayalar & $>1500$ & - & - \\
\hline$Z B$ & Az ayrışmış, orta sağlam kayalar & $760-1500$ & - & - \\
\hline$Z C$ & $\begin{array}{l}\text { Çok sık kum, çakıl ve sert kil tabakalar } \\
\text { veya ayrışmış, çok çatlaklı zayıf kayalar }\end{array}$ & $360-760$ & $>50$ & $>250$ \\
\hline$Z D$ & $\begin{array}{l}\text { Orta sıkl, slkı kum, çakıl veya çok } \\
\text { katı kil tabakaları }\end{array}$ & $180-360$ & $15-50$ & $70-250$ \\
\hline$Z E$ & $\begin{array}{l}\text { Gevşek kum, çakıl veya yumuşak-katı kil tabakaları } \\
\text { veya } P I>20 \text { ve } w>\% 40 \text { koşullarını sağlayan toplamda } \\
3 \text { m daha kalın yumuşak kil tabakası }(\mathrm{cu}<25 \mathrm{kPa}) \\
\text { içeren profiller }\end{array}$ & $<180$ & $<15$ & $<70$ \\
\hline$Z F$ & \multicolumn{4}{|c|}{$\begin{array}{l}\text { Sahaya özel araştırma ve değerlendirme gereken zeminler: } \\
\text { 1) Deprem etkisi altında çökme ve potansiyel göçme riskine sahip zeminler (slvılaşabilir zeminler, } \\
\text { yüksek derecede hassas killer, göçebilir zayıf çimentolu zeminler vb.), } \\
\text { 2) Toplam kalınlı̆̆ } 3 \text { metreden fazla turbo ve/veya organik içeriği yüksek killer, } \\
\text { 3) Toplam kalınlı̆̆ } 8 \text { metreden fazla olan yüksek plastisiteli (PI> }>\text { 50) killer, } \\
\text { 4) Çok kalın (> } 35 \text { m) yumuşak veya orta katı killer. }\end{array}$} \\
\hline
\end{tabular}

DBYYHY-2007'de Hemen Kullanım Performans Düzeyi (HK), Can Güvenliği Performans Düzeyi (CG) ve Göçme Öncesi Performans Düzeyi (GÖ) olmak üzere üç farklı performans düzeyi varken, TBDY-2018'de dört farklı performans düzeyi ifade edilmiştir. $\mathrm{Bu}$ performans düzeyleri TBDY-2018'de Kesintisiz Kullanım (KK), Sınırlı Hasar (SH), Kontrollü Hasar

$$
\begin{array}{cc}
R a(T)=1.5+(R-1.5) \frac{T}{T_{A}} & 0 \leq \mathrm{T} \leq T_{A} \\
R a(T)=R & T_{A}<\mathrm{T} \\
R a(T)=\frac{R}{l} & \mathrm{~T}>T_{A} \\
R a(T)=D+\left(\frac{R}{l}-D\right) \frac{T}{T_{B}} & \mathrm{~T} \leq T_{B}
\end{array}
$$

(KH) ve Göçmenin Önlenmesi (GÖ) olarak belirtilmiştir. Deprem yükü azaltma katsayıları da DBYBHY-2007 yönetmeliği'nde Eşitlik 1 ve 2 ile TBDY-2018 Yönetmeliği için Eşitlik 3 ve 4'de verilmiştir. 
Tablo 6: Deprem tasarım siniflarl

\begin{tabular}{c|l|l}
\hline DD-2 Deprem Yer Hareketi Düzeyinde Kısa Periyot & \multicolumn{2}{|c}{ Bina Kullanım Sinıfi } \\
\cline { 2 - 3 } Tasarım Spektral İvme Katsayısı (SDS) & \multicolumn{1}{|c}{ BKS =1 } \\
\hline$S D S<0.33$ & $D T S=4 a$ & $D T S=4$ \\
\hline $0.33 \leq S D S<0.50$ & $D T S=3 a$ & $D T S=3$ \\
\hline $0.50 \leq S D S<0.75$ & $D T S=2 a$ & $D T S=2$ \\
\hline $0.75 \leq S D S$ & $D T S=1 a$ & $D T S=1$ \\
\hline
\end{tabular}

Tablo 7: Bina yükseklik aralıkları

\begin{tabular}{c|l|c|c}
\hline \multirow{2}{*}{ Bina Yükseklik Sınıfı } & \multicolumn{3}{|c}{$\begin{array}{c}\text { Bina Yükseklik Sinıfları ve Deprem Sinıflarına Göre Tamamlanan } \\
\text { Bina Yükseklik Aralıkları [m] }\end{array}$} \\
\cline { 2 - 4 } & \multicolumn{1}{|c}{ DTS = 1, 1a, 2, 2a } & \multicolumn{1}{|c}{ DTS = 3, 3a } & \multicolumn{1}{c}{ DTS = 4, 4a } \\
\hline$B Y S=1$ & $H N>70$ & $H N>91$ & $H N>105$ \\
\hline$B Y S=2$ & $56<H N \leq 70$ & $70<H N \leq 91$ & $91<H N \leq 105$ \\
\hline$B Y S=3$ & $42<H N \leq 56$ & $56<H N \leq 70$ & $56<H N \leq 91$ \\
\hline$B Y S=4$ & $28<H N \leq 42$ & $42<H N \leq 56$ \\
\hline$B Y S=5$ & $17.5<H N \leq 28$ & $28<H N \leq 42$ \\
\hline$B Y S=6$ & $10.5<H N \leq 17.5$ & $17.5<H N \leq 28$ \\
\hline$B Y S=7$ & $7<H N \leq 10.5$ & $10.5<H N \leq 17.5$ \\
\hline$B Y S=8$ & $H N \leq 7$ & \multicolumn{2}{c}{$H N \leq 10.5$} \\
\hline
\end{tabular}

Bunların yanı sıra beton ve çelik malzeme sınıfları ve taşıyıcı sistem boyutlarında önemli değişiklikler olmuştur. DBYYHY 2007'de minimum beton sınıfı C20 iken yeni yönetmelikte bu değer C25 olarak belirlenmiştir. Minimum dikdörtgen kolon boyutları $25 \times 30 \mathrm{~cm}$ iken yeni yönetmelikte $30 \times 30 \mathrm{~cm}$ olarak belirlenmiş̧ir.

\subsection{Veri}

Bu bölümde, örnek olarak seçilen bir betonarme bina için her iki yönetmelik için ayrı ayrı yapısal analizler gerçekleştirilerek, her iki yönetmelik için değişimler incelenmiştir. Yazılım programı olarak İdeCAD kullanılmışıı (İdeCAD, 2013). Yapılarda malzeme modelleri yapı deprem davranışlarını doğrudan etkilemektedir (Iş̧k vd., 2019). Beton ve çelik için yazılımda yer alan modeller kullanılmıştır. Yapı; bodrum, zemin ve on üç normal kat olmak üzere toplamda on beş kattan oluşmaktadır. Yapının toplam yüksekliği $46.10 \mathrm{~m}$, rijit bodrum üst yapı yüksekliği $43.10 \mathrm{~m}$, rijit bodrum katsayısı 1, maksimum kat yüksekliği $3.70 \mathrm{~m}$ ve maksimum kiriş açıklığı 6.25 metredir. Yapıda 17 adet rijit diyafram bulunmaktadır. Yapının genel görünümü Şekil 3a'da, yazılımdan elde edilen üç boyutlu modeli Şekil 3b'de ve kat kalıp planı Şekil 4'de gösterilmektedir. Yapısal tüm özellikler her iki yönetmelik için aynı seçilmiştir. Yeni yönetmelikle birlikte gelen yeni parametrelerden biri olan Dayanım Fazlalığı Katsayısı (D) yapı taşıyıcı sistem durumu ve bina yükseklik durumuna göre belirlenmektedir. Yapının süneklik düzeyi yüksek olduğundan ve bina yükseklik durumundan dolayı dayanım fazlalığı katsayısı $\mathrm{X}$ ve $\mathrm{Y}$ doğrultularında 2.5 olarak belirlenmiştir. Yapı kullanım amacı, konut/işyeri olarak değerlendirilmiş ve bina önem katsayısı (I) 1 alınmıştır. Çalışmada seçilen örnek bina 15 katlı olup, bu yükseklikteki binalar için deprem yönetmeliklerinde öngörülen ve kullanılan yazılım içerisinde yer alan hesap esasları otomatik olarak seçilmiştir. Eksantrisite oranı 0.05 , süneklik düzeyi her iki doğrultu için yüksek olarak dikkate alınmıştır. Deprem bölgesi olarak 2. bölge, yerel zemin sınıfı ise Z1 olarak dikkate alınmışıtır. $\mathrm{Bu}$ durum için etkin yer ivme katsayısı (Ao) 0.30 olmaktadır. DBYBHY-2007'ye göre spektrum karakteristik periyotları olan $\mathrm{T}_{\mathrm{A}}=0.10$ ve $\mathrm{T}_{\mathrm{B}}=0.30$ değerleri elde edilmiştir. Zemin etüd raporu dikkate alınarak zemin yatak katsayısı $3600 \mathrm{tf} / \mathrm{m} 3$ olarak dikkate alınmıştır. Malzeme seçimi yapılırken TBDY-2018'e uygunluk göstermesi adına C25-B420C seçilmiştir. TBDY-2018 için deprem parametre değerleri, Türkiye Deprem Tehlikesi Haritası İnteraktif Web Uygulaması üzerinden yapının yapılacağı coğrafi konum dikkate alınarak elde edilmiştir. Deprem Tasarım Sınıfı (DTS) yeni eklenen parametreler içerisinde bulunmaktadır. Kısa periyot tasarım ivme değeri ve DD-2 yer hareketi düzeyinin ortak paydası bölümü altında oluşturulmuştur. Ele alınan yapıda kısa periyot değeri 0.2632 olup, bu değer belirtilen ivme katsayısı değerinden küçük olduğu için ve yer hareketi düzeyi DD-2 olduğundan tasarım sınıfı 4 olarak belirlenmiştir. 


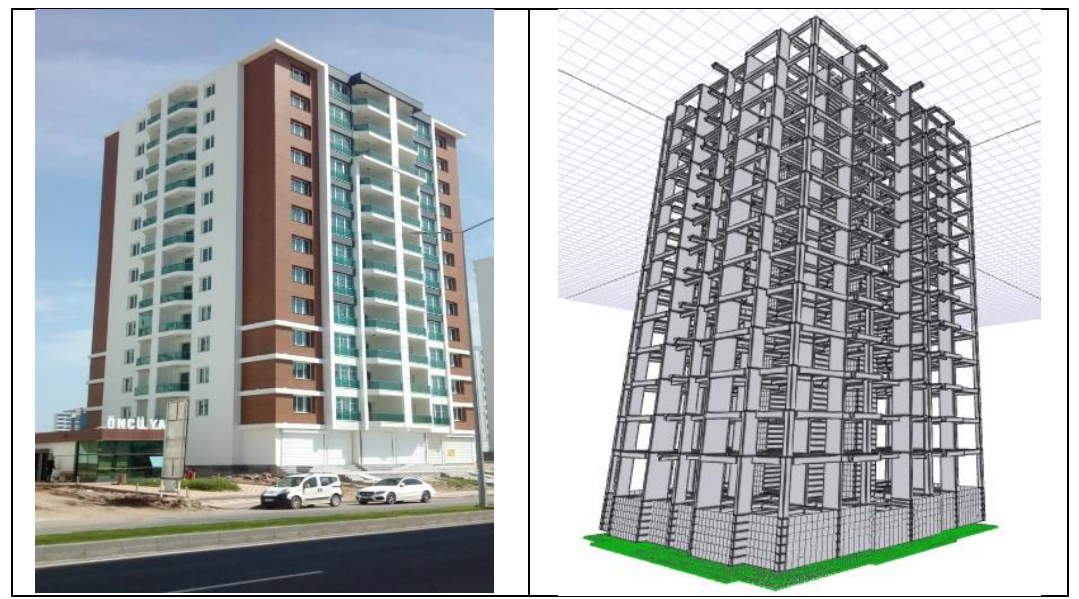

Şekil 3:(a) Bina genel görünümü, (b) Binanın ü̧̧ boyutlu modellemesi

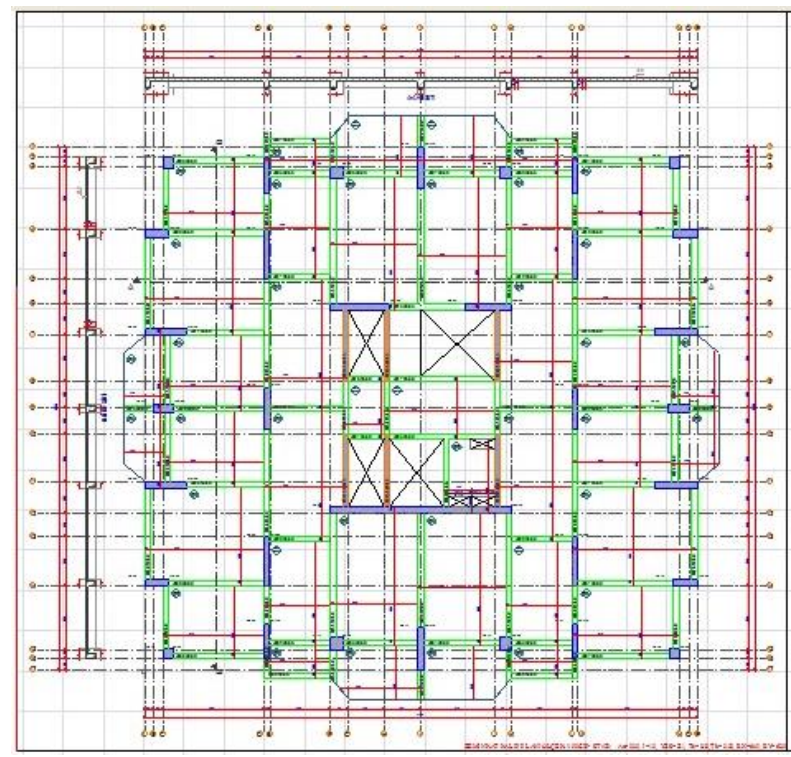

Şekil 4: Yapı kat kalıp plan

\section{Bulgular}

DBYBHY-2007 ve TBDY-2018 dikkate alınarak örnek olarak seçilen yapı için yapısal analizler ayrı ayrı gerçekleştirilmiştir. Her iki deprem yönetmeliği için yapısal analizlerden elde edilen sonuçlar Tablo 8'de gösterilmiştir.

Bina performans hedefi ve uygulama tasarımı, deprem yer hareketi düzeyi, tasarım sınıfı ve bina yüksekliğine bağlı olarak oluşturulan yeni bir parametredir. Bu şartlar dâhilinde yapının performans hedefi kontrollü hasar sınıfi içerisinde olup, uygulama tasarımı yaklaşımı ise "dayanıma göre tasarım” olarak belirlenmiştir.
Spektrum karakteristik periyotları olan $T_{A}$ ve $T_{B}$ değerleri, DBYBHY-2007 için yerel zemin sınıfına bağlı olarak belirtilen şartlara uygun olarak alınmaktaydı, yeni yönetmeliğin yürürlüğe girmesiyle Türkiye Deprem Tehlike Haritaları İnteraktif Web Uygulaması dahilinde yapı konum bilgileri girilerek bu değerlere ulaşılmaktadır. DBYBHY-2007 için yapı spektrum periyotları Z1 zemin sınıfı için $0.10 \mathrm{~s}$ ve $0.30 \mathrm{~s}$ değerleri arasında değer alırken, bu periyot değerleri TBDY-2018 için uygulama yardımı ile $0.08 \mathrm{~s}$ ve $0.41 \mathrm{~s}$ aralığı olarak belirlenmiştir. Son iki deprem yönetmeliğnde spektrum karakteristik periyotları ve katsayılarının hesaplanmasındaki değişiklikler, binanın taban kesme kuvveti ve diğer parametrelerde farklı etkilere sebep olmuştur

Tablo 8: Yapısal analiz sonucu elde edilen değerlerin karşılaştırılması

\begin{tabular}{l|c|c}
\hline \multicolumn{1}{c|}{ Parametre } & DBYBHY 2007 & TBDY 2018 \\
\hline Bina Önem Katsayısı (I) & 1 & 1 \\
\hline Bina Kullanım Sinıfı (BKS) & - & 3 \\
\hline Dayanım Fazlalı̆̆ Katsayısı (X/Y) & - & $2.5 / 2.5$ \\
\hline Deprem Yer Hareketi Düzeyi & $\begin{array}{c}\text { Gruplandırlmamıs-Tek } \\
\text { düzey }\end{array}$ & DD2 \\
\hline Deprem Tasarım Sinıfı (DTS) & - & 4 \\
\hline
\end{tabular}


European Journal of Science and Technology

\begin{tabular}{|c|c|c|}
\hline Bina Yükseklik Sınıfı & - & 4 \\
\hline Bina Performans Hedefi & - & Kontrollü hasar \\
\hline $\begin{array}{l}\text { Taşıyıcı Sistem Davranış Katsayısı } \\
\text { (R) } X\end{array}$ & 6.49 & 7.00 \\
\hline $\begin{array}{l}\text { Taşıyııı Sistem Davranış Katsayısı } \\
\text { (R) Y }\end{array}$ & 6.25 & 7.00 \\
\hline Deprem Bölgesi & 2 & - \\
\hline Yerel Zemin Sinifi & $Z 1$ & $Z A$ \\
\hline Spektrum Karakteristik Periyotları & $\begin{array}{l}T_{A}: 0.10 \\
T_{B}: 0.30\end{array}$ & $\begin{array}{l}T_{A}: 0.08 \\
T_{B}: 0.41\end{array}$ \\
\hline $\begin{array}{l}\text { Kisa Periyot Harita Spektral İvme } \\
\text { Katsayıs }\left(S_{S}\right)\end{array}$ & - & 0.329 \\
\hline $\begin{array}{l}1.0 \text { saniye periyot için harita } \\
\text { spektral ivme katsayıss }\end{array}$ & - & 0.135 \\
\hline $\begin{array}{l}\text { Kisa periyot tasarım spektral ivme } \\
\text { katsayıs }\left(S_{D S}\right)\end{array}$ & - & 0.2632 \\
\hline $\begin{array}{l}1.0 \text { saniye periyot için tasarım } \\
\text { spektral ivme katsaylsı }\left(S_{D I}\right)\end{array}$ & - & 0.108 \\
\hline En büyük yer ivmesi $(g)(P G A)$ & 0.3 & 0.146 \\
\hline En büyük yer hızı (PGV) & - & 10.724 \\
\hline Yükleme Durumları & $\begin{array}{l}E_{X} \text { ve } E_{Y} \text { doğrultularında } \\
\text { yükleme öngörülmüş̧ür. }\end{array}$ & $\begin{array}{c}E_{X}, E_{Y} \text { ve } E_{Z} \text { doğ. yükleme } \\
\text { öngörülmüştür. }\end{array}$ \\
\hline Kesit Kontrolü & Yetersiz elemanlar var & $\begin{array}{c}\text { Tüm kesit elemanlarl } \\
\text { yeterlidir. }\end{array}$ \\
\hline Al düzensizliği & $\begin{array}{c}\text { Bütün katlarda A1 } \\
\text { düzensizliği } \\
\text { sağlanamamıştır. } \\
\eta_{i(\max )=1.39>1.2(1 . k a t)} \\
\text { dinamik analiz yapılmıştır }\end{array}$ & $\begin{array}{c}\text { Bütün katlarda A1 } \\
\text { düzensizliği koşulu } \\
\text { sağlanamamıştır. } \\
\eta_{i(\max )}=1.62>1.2(2 . \mathrm{kat}) \\
\text { dinamik analiz yapılmıştır }\end{array}$ \\
\hline Hesap Yöntemi & $\begin{array}{c}\text { Dinamik hesap yöntemi } \\
\text { kullanılmıştır. }\end{array}$ & $\begin{array}{c}\text { Tepki spektrumu yöntemi } \\
\text { kullanılmıştır. }\end{array}$ \\
\hline $\begin{array}{l}\text { Toplam Deprem Yükü }(X) \\
\text { Toplam Deprem Yükü }(Y)\end{array}$ & $\begin{aligned} V t & =324.15(t f) \\
V t & =412.84(t f)\end{aligned}$ & $\begin{array}{l}V t=135.43(t f) \\
V t=143.74(t f)\end{array}$ \\
\hline Yapı Doğal Titreşim Periyodu & $\begin{aligned} T_{A}=0.10 & \leq T_{B}=0.30 \leq T r \\
& =1.31\end{aligned}$ & $\begin{array}{c}T_{A}=0.08 \leq T_{B}=0.41 \leq T r= \\
1.9\end{array}$ \\
\hline Spektrum Katsaylsl & $S(T)=0.77$ & 0.05 \\
\hline Hesaba Katılan Mod Sayısı & 18 & 15 \\
\hline Kiriş Statik Sonuçları & $\begin{array}{c}\text { Tmax: } 4.12[\mathrm{tfm}](\mathrm{K} 765) \\
V \max : 14.93[\mathrm{tf}](\mathrm{K} 250) \\
\text { Mmax: } 16.92[\mathrm{tfm}](\mathrm{K} 313)\end{array}$ & $\begin{array}{c}\text { Tmax: }-2.36[\mathrm{tfm}](\mathrm{K} 1213) \\
V \max : 11.20[\mathrm{tf}](\mathrm{KB} 160) \\
\text { Mmax:-14.00[tfm] }(\mathrm{K} 1153)\end{array}$ \\
\hline Kiriş Kesme Donatısı & $\begin{array}{l}V d<0.22 b_{w} d f_{c d} \text { şartı tüm } \\
\text { kirişlerde sağlanmiştır. }\end{array}$ & $\begin{array}{c}\text { Ve }<0.85 b_{w} d \sqrt{f_{c k}} \\
\text { Şartı tüm kirişlerde } \\
\text { sağlanmıştır. }\end{array}$ \\
\hline Kiriş Kesme Güvenliği & $\begin{array}{c}V_{e}<0.22 b_{w} d f_{c d} \text { şartı tüm } \\
\text { kirişlerde sağlanmıştır. }\end{array}$ & $\begin{array}{c}V_{d}<0.85 b_{w} d \sqrt{ } f_{c k} \\
\text { Tümkirişlerdesağlanmıştır. }\end{array}$ \\
\hline Kolon Statik Sonuçları & $\begin{array}{l}M_{\max }:-1760.62[\mathrm{tfm}](\mathrm{PZO}) \\
T_{\max }:-3.29[\mathrm{tfm}](\mathrm{P} 207) \\
V_{\max }: 297.01[\mathrm{tf}](\mathrm{PB107}) \\
N_{\max }:-857.02[\mathrm{tf}](\mathrm{PB} 107)\end{array}$ & $\begin{array}{l}M_{\max }: 870.56[\mathrm{tfm}](\mathrm{PZO7}) \\
T_{\max }: 4.92[\mathrm{tfm}](\mathrm{P} 307) \\
V_{\max }: 292.76[\mathrm{tf}](\mathrm{P} 107) \\
N_{\max }:-1030.81[\mathrm{tf}](\mathrm{PB} 107)\end{array}$ \\
\hline Kolon Kesme Güvenliği & $\begin{array}{c}V_{e} \leq 0.22 b_{w} d f_{\text {cd }} \text { koşulu tüm } \\
\text { kolonlarda sağlanmıştır. }\end{array}$ & $\begin{array}{l}V_{e} \leq 0.85 A_{w} \sqrt{ } f_{c k} \text { koşulu tüm } \\
\text { kolonlarda sağlanmıştır. }\end{array}$ \\
\hline $\begin{array}{l}\text { Kolonlarda Maksimum Normal } \\
\text { Kuvvet Kontrolü }\end{array}$ & $\begin{array}{c}0.5 A_{c} f_{c k} \geq N_{D \max } \\
\text { koşulu tüm kolonlarda } \\
\text { sağlanmıştır }\end{array}$ & $\begin{array}{l}0.4 A_{c} f_{c k} \geq N_{\text {Dmax }} \text { koşulu tüm } \\
\text { kolonlarda sağlanmiştır }\end{array}$ \\
\hline Perde Statik Sonuçları & $\begin{array}{c}M_{\max }: 214.83[\mathrm{tfm}](\mathrm{PB} 119) \\
T_{\max }:-13.71[\mathrm{tfm}](\mathrm{PB} 115) \\
V_{\max }: 218.18[\mathrm{tf}](\mathrm{PB} 117) \\
N_{\max }:-349.29[\mathrm{tf}](\mathrm{PB} 119)\end{array}$ & $\begin{array}{c}M_{\max }: 222.80[\mathrm{tfm}](\mathrm{PZ20}) \\
T_{\max }:-9.36[\mathrm{tfm}](\mathrm{PB} 115) \\
V_{\max }: 53.09[\mathrm{tf}](\mathrm{PB} 119) \\
N_{\max }:-378.47[\mathrm{tf}](\mathrm{PZ20})\end{array}$ \\
\hline
\end{tabular}




\begin{tabular}{|c|c|c|}
\hline Perde Kesme Güvenliği & $\begin{array}{l}V_{e} \leq 0.22 A_{c} h f_{c d} \text { şartı tüm } \\
\text { perdelerde sağlanmiştır. }\end{array}$ & $\begin{array}{c}V_{e} \leq V_{\text {emax }} \text { şartı tüm } \\
\text { perdelerde sağlanmıştır. }\end{array}$ \\
\hline Radye Temel Statik Sonuçları & $\begin{array}{l}M 11_{(\max )}:-95.38[\mathrm{tfm}] \\
M 22_{(\max )}: 54.82[\mathrm{tfm}]\end{array}$ & $\begin{array}{l}M 11_{(\max )}: 91.57[\mathrm{tfm}] \\
M 22_{(\max )}: 60.89[\mathrm{tfm}]\end{array}$ \\
\hline $\begin{array}{l}\text { Radye Temel Betonarme Donatı } \\
\text { Hesabl }\end{array}$ & $\begin{array}{c}\text { Mevcut donatisl gerekenden } \\
\text { az olan radye temeller var. } \\
\text { DB136 }\end{array}$ & $\begin{array}{c}\text { Tüm radye temellerde } \\
\text { gereken donatı koşulları } \\
\text { sağlanmıştır. }\end{array}$ \\
\hline Döşeme Tipi & Kaset döşeme & Kaset döşeme \\
\hline
\end{tabular}

BA kesit hesabında esas alınmak üzere en kesit ağırlık merkezinde hesaplanan eşdeğer çubuk tesirlerinden eğilme momenti kullanılarak, perde tabanında devrilme momenti hesaplanmaktadır. Devrilme momentini oluşturan kuvvetler Tablo 9'da, deprem momentleri de Tablo 10'da belirtilmektedir.

Tablo 9: Deprem kuvvetleri

\begin{tabular}{c|c|c|c|c}
\hline Kat & $\mathbf{F}_{\mathbf{x}} \mathbf{( 2 0 0 7 )}[\mathbf{t f}]$ & $\mathbf{F}_{\mathbf{y}} \mathbf{( 2 0 0 7 )}[\mathbf{t f}]$ & $\mathbf{F}_{\mathbf{x}} \mathbf{( 2 0 1 8 )}[\mathbf{t f}]$ & $\mathbf{F}_{\mathbf{y}} \mathbf{( 2 0 1 8 )}[\mathbf{t f}]$ \\
\hline 13 & 10.92 & 14.32 & 5.47 & 6.92 \\
\hline 12 & 61.75 & 78.66 & 29.00 & 34.88 \\
\hline 11 & 44.76 & 56.60 & 18.45 & 20.52 \\
\hline 10 & 30.95 & 40.60 & 10.34 & 10.38 \\
\hline 9 & 21.00 & 30.01 & 5.82 & 5.76 \\
\hline 8 & 14.82 & 22.96 & 3.89 & 4.06 \\
\hline 7 & 12.46 & 19.56 & 2.96 & 3.04 \\
\hline 6 & 13.25 & 19.23 & 2.62 & 3.47 \\
\hline 5 & 15.62 & 20.50 & 3.65 & 5.39 \\
\hline 4 & 18.20 & 22.52 & 6.50 & 7.08 \\
\hline 3 & 19.83 & 23.69 & 9.90 & 8.64 \\
\hline 2 & 19.90 & 22.74 & 11.70 & 10.27 \\
\hline 1 & 18.32 & 19.79 & 11.62 & 10.38 \\
\hline Zemin & 14.32 & 14.80 & 10.89 & 9.68 \\
\hline Bodrum & 199.25 & 199.25 & 996.27 & 996.27 \\
\hline
\end{tabular}

Tablo 10: Deprem momentleri

\begin{tabular}{c|c|c|c|c}
\hline Kat & $\mathbf{M}_{\mathbf{x}} \mathbf{( 2 0 0 7 )}[\mathbf{t f m}]$ & $\mathbf{M}_{\mathbf{y}}(\mathbf{2 0 0 7})[\mathbf{t f}]$ & $\mathbf{M}_{\mathbf{x}} \mathbf{( 2 0 1 8 )}[\mathbf{t f m}]$ & $\mathbf{M}_{\mathbf{y}} \mathbf{( 2 0 1 8 )}[\mathbf{t f m}]$ \\
\hline 13 & 503.27 & 660.03 & 252.16 & 318.82 \\
\hline 12 & 2636.68 & 3358.78 & 1238.1 & 1489.42 \\
\hline 11 & 1776.82 & 2246.87 & 732.48 & 814.62 \\
\hline 10 & 1135.99 & 1489.91 & 379.6 & 381.12 \\
\hline 9 & 707.73 & 1011.46 & 195.99 & 194.18 \\
\hline 8 & 454.86 & 704.76 & 119.57 & 126.60 \\
\hline 7 & 345.21 & 541.80 & 82.02 & 84.21 \\
\hline 6 & 327.33 & 474.86 & 64.64 & 85.70 \\
\hline 5 & 338.93 & 444.89 & 79.12 & 116.95 \\
\hline 4 & 340.33 & 421.09 & 121.55 & 132.43 \\
\hline 3 & 311.36 & 371.97 & 155.37 & 135.61 \\
\hline 2 & 252.77 & 288.76 & 148.58 & 130.42 \\
\hline 1 & 177.74 & 191.99 & 112.7 & 100.64 \\
\hline Zemin & 95.97 & 99.17 & 72.96 & 64.84 \\
\hline Bodrum & 597.76 & 597.76 & 2988.82 & 2988.82 \\
\hline Toplam & 10354.89 & 13204.94 & 6859.20 & 7305.76 \\
\hline
\end{tabular}


Katlara ait $\mathrm{X}$ ve $\mathrm{Y}$ doğrultularındaki deprem kuvvetleri, Fx ve Fy, zemin kat dâhil onbeş kat boyunca azalma gösterirken bodrum katında bir artış meydana gelmiştir. $\mathrm{X}$ ve $\mathrm{Y}$ doğrultularında kuvvet değişim diyagramları Şekil 5'de gösterilmiştir.

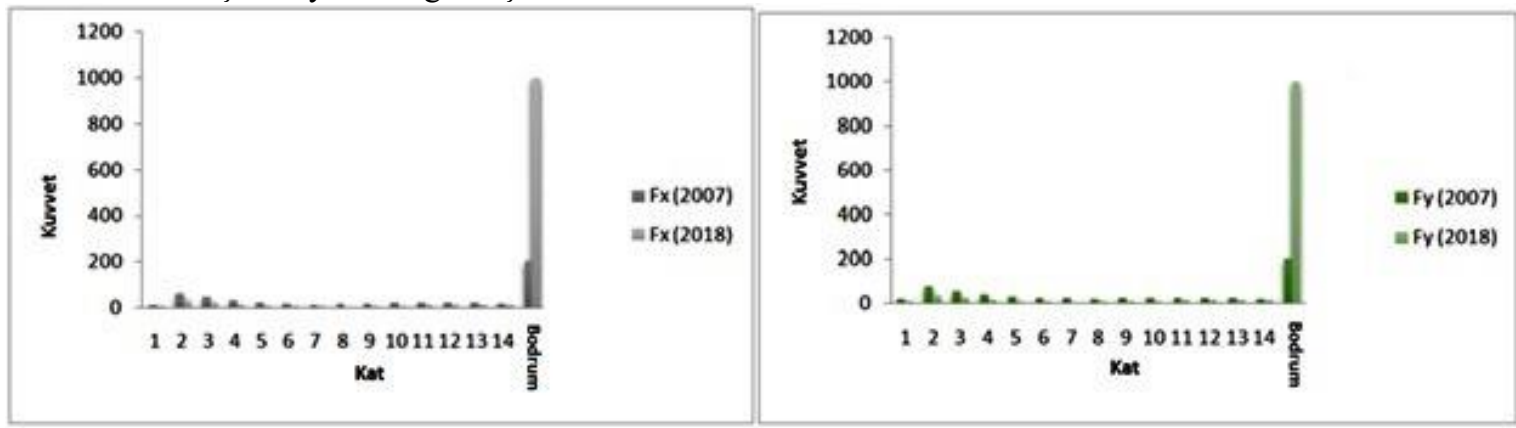

Şekil 5: X ve Y doğrultularında kuvvet değişimleri

TBDY-2018 için X ve Y doğrultularında hesaplanan moment değerleri, zemin kat ve diğer üst katların tümünde DBYBHY2007 'ye göre düşük değerler almıştır. Ancak sadece bodrum katta

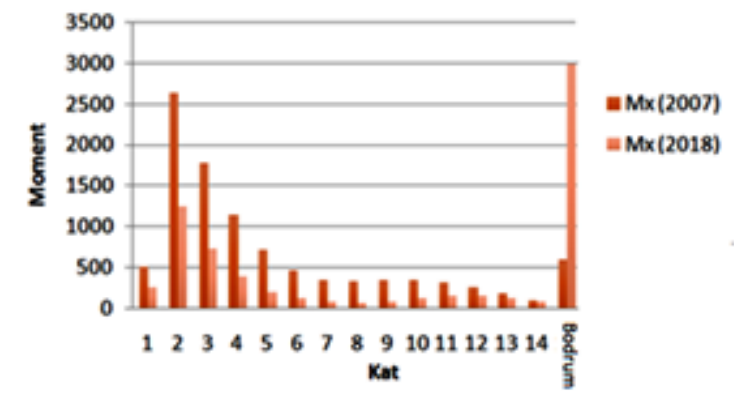

moment değeri TBDY-2018'e göre yapılan analiz sonucunda büyük çıkmıştır (Şekil 6).

Şekil 6: X ve Y doğrultulart için moment değişimi

Taşıyıcı sistem türüne göre belirlenen tasarım davranış katsayısı her iki yönetmelikte de bulunmaktadır. DBYBHY2007'de sadece yapının süneklik durumuna göre belirlenirken, TBDY-2018'de ise bina yükseklik sınıfı (BYS) ve dayanım fazlalığı katsayısı (D) şartı da eklenmiştir. Belirtilen şartlar dâhilinde örnek yapının X ve Y doğrultusunda davranış katsayısı 6.49 ve 6.25 olurken, bu değer TBDY-2018'e göre 7.0 olarak belirlenmiştir. DBYBHY-2007'ye göre X ve Y doğrultularında taşıyıcı sistem davranış katsayısı hesaplanırken $\mathrm{R}=10-4$. $\alpha$ s ile hesaplanmıştır. $\mathrm{X}$ doğrultusunda $\alpha \mathrm{S}=0.878, \mathrm{Y}$ doğrultusunda ise bu değer 0.938 olarak hesaplamıştır. $\mathrm{Bu}$ değerler dikkate alındığında $\mathrm{X}$ doğrultusu için davranış katsayısı 6.49, Y doğrultusu için 6.25 olarak dikkate alınmıştır.

Yükleme durumları 2007 yönetmeliğinde sadece Ex ve Ey boyutu üzerinde etki gösterirken, TBDY-2018'de ek olarak Ez doğrultusunda düşey deprem etkisi de dahil edilmiştir. Yap1 üzerinde kesit kontrolü yapıldığında, DBYBHY-2007'de şartlarına göre DB136 bodrum döşemesi üzerinde kesit yetersizliği tespit edilirken güncel yönetmeliğe göre tüm kesit elemanları yeterli olarak tespit edilmiştir.

Hesap yöntemi seçiminde DBYBHY-2007'de belirtilen şartlara bağlı olarak yapıda dinamik hesap yöntemi kullanılırken, TBDY-2018'de ise tepki spektrumu yöntemi kullanılmıştır. Deprem etkisi altında yapıya etki eden toplam eşdeğer deprem yükü, Vt, X doğrultusunda DBYBHY-2007'de 324.15 tf, TBDY2018 için 135.43 tf, Y doğrultusunda DBYBHY-2007'de 414.84 tf, TBDY-2018 bu değer 143.74 tf olarak hesaplanmıştır.
Deprem hesabı için kullanılması gereken bir diğer parametre olan yapının doğal titreşim periyodu DBYBHY-2007 için 1.31s olarak hesaplanırken bu değer güncel deprem yönetmeliğine göre 1.9 s olarak hesaplanmıştır. Hesaba katılan mod sayısı DBYBHY2007 için 18, TBDY-2018 için de 15 olarak elde edilmiştir.

Temel tipi olarak radye temel kullanılmıştır. Radye temel statik hesaplarına bakıldığında moment değerleri, DBYBHY2007 için $\mathrm{M} 11=95.38 \mathrm{tfm}$ ve $\mathrm{M} 22=54.82 \mathrm{tfm}$ olarak hesaplanmıştır. TBDY-2018 için M11 $=91.57 \mathrm{tfm}$ ve M22 $=60.89$ tfm değerlerini almıştır. Genel olarak moment değerlerinde bir azalma meydana gelmiştir. Temel için yapılan donatı hesaplamalarında DBYBHY-2007 için donatı yetersizliği tespit edilirken, TBDY-2018 için tüm donatı koşulları sağlanmıştır.

\section{Sonuçlar}

Depreme dayanıklı yapı tasarım kurallarının zaman içerisinde değişime uğraması bir zorunluluk olarak ortaya çıkmaktadır. Türkiye'de de bu süreç, farklı tarihlerdeki deprem yönetmeliklerinden net bir şekilde anlaşılmaktadır. Her yeni yönetmeliğin yapısal anlamda bir kazanım olduğu gözden kaçmamalıdır.

$\mathrm{Bu}$ çalışma kapsamında, Türkiye'de kullanılan son iki deprem yönetmeliği olan DBYBHY-2007 ile TBDY-2018 arasındaki farklar, aynı yapı tasarımı üzerindeki, yapısal analizler açısından irdelenmiştir. Her iki yönetmelikteki farklar, ele alınan konular itibariyle madde madde gözden geçirilmiş ve 15 katlı bir yapının tasarımı sırasında ortaya çıkan farkları örneklemeli olarak 
ortaya konulmuştur. Bu sırada ticari bir yazılım olan ideCAD yazılımının hem DBYBHY-2007 hem de TBDY-2018'e uygun olan sürümleri ile analiz yapılmıştır. Deprem yükleri altında yapılacak analiz ve değerlendirmeler ile bina tasarımında kullanılacak hesap yaklaşımlarında TBDY-2018 ile DBYBHY2007 önemli ölçüde değişikler bulunmaktadır. Deprem tasarım sınıfı (DTS), bina yükseklik sınıfı (BYS), deprem yer hareket düzeyi (DD) ve düşey elastik tasarım spektrum eğrileri gibi kavramlar ilk kez TBDY-2018'de kendine yer bulmuştur. Yeni yönetmelik ile faya yakınlık durumu da dikkate alınmaya başlanmıştır. DBYBHY-2007'de performans kavramı ve performans düzeyleri sadece mevcut yapılar için geçerli iken TBDY-2018 ile bu kavram ve düzeyler yeni binalar için de kullanılmaya başlanmıştır. Her iki yönetmelikte hesap yöntemleri aynı başlıklar altında toplansa da yapısal hesaplamalarda önemli farklılıklar bulunmaktadır. $\mathrm{Bu}$ farklılıklar analiz sonuçlarına yansımıştır.

TBDY-2018 ile sabit deplasman platosu ve bu platoyu belirleyen TL ve TLD yani yatay ve düşey tasarım spektrumları için sabit yer değiştirme bölgesine geçiş periyotları belirtilmiştir. Yatay elastik tasarım spektrumu için bu değer $\mathrm{TL}=6.0 \mathrm{~s}$ ve düşey içinse TLD $=3.0$ s olarak kabul edilmektedir. Bununla deplasman istemlerinin kontrolsüz olarak artması önlenmektedir.

Yapıların dinamik analizi için hesaba katılacak yeterli titreşim mod sayısı, her bir mod için hesaplanan etkin kütlelerin toplamının bina toplam kütlesinin oranına bağlı olarak hesap edilmektedir. DBYBHY- 2007 bu oran \%90 iken, TBDY-2018'de bu oran \%95 olarak değişmiştir. Bu ve diğer değişimler hesaba katılan yeterli mod sayısını değiştirmiştir.

TBDY-2018'de BA taşıyıcı sistemler için kullanılan etkin kesit rijitliklerine bağlı hesaplanan yerdeğiştirme değerleri DBYBHY-2007'ye göre daha fazladır. Bu durum aynı zamanda sınır durum olarak belirtilen göreli kat öteleme değerlerini TBDY-2018'de artması anlamına gelmektedir. Bu açıdan her iki yönetmelik için hesaplanan burulma düzensizlik katsayıları, farklı değerler almıştır. Daha fazla yerdeğiştirme talepleri olduğundan TBDY-2018 için hesaplanan doğal titreşim periyodu DBYBHY2007'ye göre daha büyük çıkmıştır.

Son deprem yönetmeliğindeki en büyük değişim, sahaya özgü deprem parametrelerinin hesaplanmasında görülmektedir. Sahaya özgü tasarım spektrumlarının kullanılması sırasında yapıdan beklenen yerdeğiştirme değerleri daha sağlıklı bir şekilde elde edilmektedir. DBYBHY-2007 için deprem tehlikesi bölgesel bazda bir değerlendirmeye tabi tutulurken, bu durum TBDY2018'de coğrafik konuma özgü olarak özel olarak hesaplanmaktadır. DBYBHY-2007 için deprem bölgeleri için derecelendirme yapılmakta iken yeni yönetmelik ile bu sınıflandırma ortadan kalkmıştır. Bu bağlamda en büyük yer ivmesi değeri (PGA), çalışmada ele alınan örnek binanın yeri bakımından ele alındığında, DBYBHY-2007'de 0.3 g değeri, TBDY-2018'e göre kullanılan web uygulaması yardımı ile 0.149 $\mathrm{g}$ değerini almaktadır. Yeni deprem yönetmeliği ile etkin yer ivme katsayısı $\left(\mathrm{A}_{\mathrm{o}}\right)$ 'nın yerine kısa periyot spektral ivme katsayısı $\left(\mathrm{S}_{\mathrm{S}}\right)$ ve $1.0 \mathrm{~s}$ için spektral ivme katsayısı $\left(\mathrm{S}_{1}\right)$ kullanılmaya başlanmıştır.

DBYBHY-2007'de zeminler grup ve sınıf olarak ayrı ayrı isimlendirilmekte iken güncel yönetmelik ile tek çatı altında toplanmıştır. Daha önce dört farklı zemin sınıfı var iken yeni yönetmelik ile altıya çıkmıştır. Zemin sınıfları ve grupları birleştirilmiş altı farklı yerel zemin sınıfı ifade edilmiştir. Yerel zemin koşullarının etkisini daha belirgin bir şekilde ortaya koymak adına yerel zemin etki katsayıları (Fs ve F1) güncel yönetmelikte kendine yer bulmuştur.

Yapısal hesaplamalara esas olacak deprem parametreleri kullanıcıdan bağımsız olarak doğrudan Türkiye Deprem Tehlike Haritaları İnteraktif Web uygulaması hayata geçirilmiştir. $\mathrm{Bu}$ uygulama yerel zemin sınıfının ZF olması durumu hariç olmak üzere diğer 5 farklı yerel zemin koşulu için doğrudan kullanılabilmektedir. ZF için sahaya özel araştırma ve değerlendirme yapılması gerekmektedir. Yerel zemin koşullarının yapılardaki deprem etkilerini doğrudan etkilediğinin bir sonucu olarak güncel yönetmelik yerel zemin koşullarına çok daha fazla önem vermektedir. Güncel deprem yönetmeliğinde, Türkiye Deprem Tehlike Haritaları kullanılarak yatay elastik tasarım ivme spektrumu SDS değerine bağlı olarak değişken pik değerler alabilmektedir. Ancak 2007 yönetmeliğinde maksimum ivme değeri spektrumda $2.5 \mathrm{~g}$ ile sinırlandırılmıştır. Bu bir önceki yönetmelikte köşe periyot değerleri sabit değerler almakta iken güncel yönetmelikte SDS ve SD1 katsayılarına bağlı olarak coğrafik konuma göre değişkenlik göstermektedir. Bunun yanı sıra zemin sınıflarından dolayı dikkate alınan ivme katsayıları da değişmiştir. Bu ve buna benzer değişikliklerden dolayı spektrum karakteristik periyotları ve spektrum eğrilerindeki değişikliklerde kaçınılmaz olmuştur.

Malzeme dayanımı açısından DBYBHY-2007'de öngörülen beton sınıfları C20-C50 aralığında iken yeni yönetmelik ile C25C80 olarak belirlenmiştir. Beton üst sınıfının değişimi gelişen beton teknolojisi ile doğrudan ilişkilidir. Beton alt sınıf değişiminin de hem bu gelişme hem de betonarme yapılarda hasarın doğrudan beton dayanımı ile ilgili olmasından kaynaklanmaktadır. Ayrıca taşıyıcı sistem eleman boyutları ile ilgilide önemli değişiklikler olmuştur. Örneğin dikdörtgen kesitli bir kolon için minimum boyut $250 \times 300 \mathrm{~mm}$ iken güncel yönetmelik ile $300 \times 300 \mathrm{~mm}$ olmuştur. Dairesel kesitli kolonlarda ise çap $300 \mathrm{~mm}$ 'den $350 \mathrm{~mm}$ 'ye çıkarılmıştır. Betonarme perdelerde $200 \mathrm{~mm}$ olan minimum kalınlık değeri $250 \mathrm{~mm}$ 'ye çıkarılırken kenar oranı 7 değerinden 6'ya düşürülmüştür. Kolon, kiriş ve perdeler için kesme kuvveti hesaplanırken DBYBHY2007'den farklı olarak TBDY-2018'de ek olarak dayanım fazlalığı katsayısı (D) kullanılmaya başlanmıştır. Dayanım fazlalığı katsayısı BA yapılarda $\mathrm{D} \geq 2$ olarak alınacağından daha büyük kesme kuvvetlerinin dikkate alınması gerektiğini belirtmektedir. $\mathrm{Bu}$ durum taşıyıcı sistem elemanlarında deprem sonrası gözlemlenen kesme hasarlarının dikkate alındığının bir göstergesidir. Güncel yönetmelik ile depremlerde yaygın olarak gözlemlenen hasarların önlenmesi için bir anlamda çözümler sunulmuştur.

\section{Teșekkür}

Bu çalışma, Bitlis Eren Üniversitesi Fen Bilimleri Enstitüsü İnşaat Mühendisliği Anabilim Dalı'nda İnşaat Yük. Müh. Kübra ADAR tarafından tamamlanan "2007 Deprem Yönetmeliği'nin 2018 Deprem Yönetmeliği ile Karşılaştırılması ve Deprem Yükü Hesabındaki Farklar" adlı yüksek lisans tezinden yararlanılarak hazırlanmıştır. IdeCAD yazılımının yeni versiyonunu kullanma konusunda yardımlarını esirgemeyen Prof. Dr. M.Cihan AYDIN'a teşekkür ederiz. 


\section{Kaynakça}

ABYYHY (1968). Afet Bölgelerinde Yapılacak Yapılar Hakkında Yönetmelik (ABYYHY-1968).

ABYYHY (1975). Afet Bölgelerinde Yapılacak Yapılar Hakkında Yönetmelik (ABYYHY-1975).

ABYYHY (1998). Afet Bölgelerinde Yapılacak Yapılar Hakkında Yönetmelik (ABYYHY-1998).

AFAD (2018). https://deprem.afad.gov.tr/ (Erişim tarihi:12.05.2019)

Aksoylu, C., \& Arslan, M.H. (2021). 2007 ve 2019 Deprem Yönetmeliklerinde Betonarme Binalar İçin Yer Alan Farklı Deprem Kuvveti Hesaplama Yöntemlerinin Karşılaştırılmalı Olarak İrdelenmesi. International Journal of Engineering Research and Development, 13(2), 359-374.

Aksoylu, C., Mobark, A., Arslan, M.H, \& Erkan, İ.H (2020). A comparative study on ASCE 7-16, TBEC-2018 and TEC2007 for reinforced concrete buildings. Revista de la construcción, 19(2), 282-305.

Aktas, G., \& Karasin, A. (2014). Experimental confirmation for the validity of Ritz method in structural dynamic analysis. Journal of Theoretical and Applied Mechanics, 52.

Alyamaç, K.E., \& Erdoğan, A.S., (2005). Geçmişten günümüze afet yönetmelikleri ve uygulamada karşılaşılan tasarım hataları. Deprem Sempozyumu, Kocaeli, 707-715.

Borcherdt, R.D. (2004). A theoretical model for site coefficients in building code provisions. In Procs. 13th World Conference on Earthquake Engineering (pp. 1-6).

Bozer, A. (2020). Tasarım Spektral İvme Katsayılarının DBYBHY 2007 ve TBDY 2018 Yönetmeliklerine Göre Karşılaştırması. Dicle Üniversitesi Mühendislik Fakültesi Mühendislik Dergisi, 11(1), 393-404.

Büyüksaraç, A., Bektaş, Ö., Yılmaz, H., \& Arısoy M.Ö. (2013). Preliminary seismic microzonation of Sivas city (Turkey) using micro tremor and refraction microtremor (ReMi) measurements, Journal of Seismology, 17(2), 425-435.

Dalyan, İ., \& Şahin, B. (2019). Mevcut Betonarme Bir Binanın 2007 ve 2018 Deprem Yönetmeliklerine Göre Deprem Yükleri Altındaki Taşıyıcı Sistem Perfomansının Değerlendirilmesi. Türk Deprem Araştırma Dergisi, 1(2), 134-147.

DBYYHY (2007). Deprem Bölgelerinde Yapılacak Yapılar Hakkında Yönetmelik. T.C. Resmi Gazete; 26454, 2007.

Emlakansiklopedisi http://emlakansiklopedisi.com/wiki/deprem yönetmeliği (Erişim tarihi: 05.10.2018)

IdeCAD (2013). İdeCAD Statik V7.020, IdeYAPI, Turkiye.

Işık, E., \& Kutanis, M. (2015). Determination of local sitespecific spectra using probabilistic seismic hazard analysis for Bitlis Province, Turkey, Earth Sciences Research Journal, 19(2), 129-134.

Işık, E., Büyüksaraç, A., \& Aydin, M.C. (2016). Effects of local soil conditions on earthquake damages. Journal of Current Construction Issues. Civil Engineering Present Problems, Innovative Solutions-Sustainable Development in Const., ed. Jarosław Górecki, BGJ Consulting, 191-198.

Işık, E., Büyüksaraç, A., Ekinci, Y.L., Aydın, M.C., \& Harirchian, E. (2020). The Effect of Site-Specific Design Spectrum on Earthquake-Building Parameters: A Case Study from the Marmara Region (NW Turkey). Applied Sciences, 10(20), 7247.
Işık, E., Ekinci, Y.L., Sayıl, N., Büyüksaraç, A., \& Aydın, M.C. (2021). Time-dependent model for earthquake occurrence and effects of design spectra on structural performance: a case study from the North Anatolian Fault Zone, Turkey. Turkish Journal of Earth Sciences, 30(2).

Işık, E., Karaşin, İ.B., \& Ulu, A.E. (2020). Eğimli Zeminlerde İnşa Edilen Betonarme Binaların Deprem Davranışlarının İncelenmesi. Avrupa Bilim ve Teknoloji Dergisi, (20), 162170.

Işık, E., Özdemir, M., Karaşin, İ.B., \& Karaşin, A., (2019). Betonarme yapılarda kullanılan malzeme modellerinin karşılaştırılması. Bitlis Eren Üniversitesi Fen Bilimleri Dergisi, 8(3), 968-984.

Karaşin, İ.B., \& Işık, E. (2017). Farklı yapı davranış katsayıları için zemin koşullarının yapı performansına etkisi, DÜMF Mühendislik Dergisi, 8(4), 661-673.

Karaşin, İ.B., Işık, E., Demirci, A., \& Aydın, M.C. (2020). Coğrafi Konuma Özel Tasarım Spektrumlarının Betonarme Yap1 Performansına Etkisi. Dicle Üniversitesi Mühendislik Fakültesi Mühendislik Dergisi, 11(3), 1319-1330.

Kemaloğlu, M. (2015). Türkiye'de afet yönetiminin tarihi ve yasal gelişimi. Akademik Bakış Dergisi, 52, 126-147.

Keskin, E., \& Bozdoğan, K.B. (2018). 2007 ve 2018 Deprem Yönetmeliklerinin Kırklareli İli Özelinde Değerlendirilmesi. Kırklareli Üniversitesi Mühendislik ve Fen Bilimleri Dergisi, 4(1), 74-90.

Nemutlu, Ö.F., Balun, B., Benli, A., \& Sarı, A. (2020). Bingöl ve Elazığ İlleri Özelinde 2007 ve 2018 Türk Deprem Yönetmeliklerine Göre İvme Spektrumlarının Değişiminin İncelenmesi. Dicle Üniversitesi Mühendislik Fakültesi Mühendislik Dergisi, 11(3), 1341-1356.

Över, S., Büyüksaraç, A., Bektaş, Ö., \& Filazi, A. (2011). Assessment of potential seismic hazard and site effect in Antakya (Hatay Province), SE Turkey, Environmental Earth Sciences, 62(2), 313-326.

Öztürk, M. (2018). 2018 Türkiye Bina Deprem Yönetmeliği ve Türkiye Deprem Tehlike Haritası ile İlgili İç Anadolu Bölgesi Bazında Bir Değerlendirme, Selçuk Teknik Dergisi, 17(2), $31-42$.

Özyurt, M. Z., \& Hayvalı, A.Z. (2020). Bir yönde perdeli 15 katlı yapının dinamik davranışının incelenmesi. AvrupaBilim ve Teknoloji Dergisi, 369-380.

Parlar, (2019). Türkiye'deki tüm deprem yönetmelikleri. www.parlar.com.tr

Sümer, Y., \& Hamsici, M. (2020). Çok Katlı Betonarme Binalarda 2018 Deprem Yönetmeliği İle Tanımlanan Spektrum Eğrilerinin Etkisi. Akademik Platform Mühendislik ve Fen Bilimleri Dergisi, 8(2), 349-354.

TBDY (2018), Türkiye Bina Deprem Yönet-meliği. T.C. Resmi Gazete; 30364, 2018.

Ulutaş, H. (2019). DBYBHY (2007) ve TBDY (2018) Deprem Yönetmeliklerinin Kesit Hasar Sınırları Açısından Kıyaslanması. Avrupa Bilim ve Teknoloji Dergisi, (17), 351359.

Yakut, A., Erberik, M.A., Ilki, A., Sucuoğlu, H., \& Akkar, S. (2014). Rapid seismic assessment procedures for the Turkish Building Stock. In Seismic Evaluation and Rehabilitation of Structures (pp. 15-35). Springer, Cham. 